\title{
Telecom Reforms in the EU: Prices and Consumers' Satisfaction
}

\author{
By Emanuele Bacchiocchi - Massimo Florio - Marco Gambaro
}

\section{Abstract}

The paper shows the impact on consumers of privatization and liberalization in the telecommunication sector for 15 EU Countries. Policy reforms are summarized by the OECD regulatory indicators (REGREF) that consider the extent of privatization, vertical disintegration, and market entry. After controlling for other country variables, first, a test of the impact of ownership and regulatory changes on consumer prices is given. In a second step, the Eurobarometer data on consumers' satisfaction about quality and prices of the telecommunication service are considered. The analysis confirms the importance of market regulation in reducing prices but minimize the role played by privatization per se. Overall, the findings offer only mixed evidence, and somehow contradict, the hypothesis that all the reforms work in a similar way across the EU countries.

Keywords: telecom industry liberalization, privatization, European consumers JEL codes: L32, L33, L96

\section{Introduction}

The telecom sector is not just one among the network industries that experienced a policy paradigm shift over the last twenty years: it has been its core laboratory world-wide and the one where the reforms started earlier. If one had to pick up a single year as the turning point, 1984 would be the most convenient one, with the parallel divestiture of AT\&T in the US and of British Telecom in the UK. The meaning of divestiture was however quite different across the two sides of the Atlantic. AT\&T was a private regulated monopolist that was broken up in seven regional Bell operating companies. British Telecom was a public corporation that after privatization was under a regime of regulated duopoly along with another privatized operator, Mercury. In both cases, institutional changes, away from regulated and integrated monopoly in the US, and from integrated public monopoly in the UK, were officially motivated by a willingness to establish competition in the industry. It has been widely acknowledged that to ensure an effective transition to a competitive market, however, divestiture policies need to be accompanied by regulatory reforms. The simple change of the ownership structures, from public to private, in fact, is not sufficient for the market to become effectively opened, breaking up the monopolies, and guaranteeing better conditions for private investors to enter the market. In most countries, governments surrendered their powers to national regulatory authorities, with the aim of overseeing and regulating the interactions between incumbents and entrant firms (Edwards \& Waverman, 2006), protecting the consumers, and ensure 
adequate infrastructure investments (Alesina, Ardagna, Nicoletti \& Schiantarelli, 2005).

At the same time, a dramatic process of technological change reshaped the industry. Regulators and law-makers had to frequently adjust their views because of entirely new developments. The new industry reform paradigm points to privatization and liberalization (Newbery, 2000).

This paper wants to test whether the reform process, as measured by regulatory indicators, is correlated with benefits to the consumers. After all the final evaluation of the reforms should be based on testing what it delivers to the users of the service. Ideally one would look to detailed case histories, considering long time series. A complementary approach would be to consider cross-country evidence. Under the latter perspective, the EU offers something near to a natural experiment. On one side, there is one policy actor, the European Commission, who pushes towards a well defined reform package, as embodied in telecom directives; on the other side, there are the member states that, more or less in compliance with the EU legislation, show big differences in reform design, sequencing, timing, market structures. Another attractive aspect of a cross-country empirical study is that, differently from other network industries, such as electricity, countries are not exogenously constrained in technology adoption by intrinsic geographic characteristics. This allows focusing on country differences in ownership, institutions, competition, and other industry features, under a common technological trend.

In the present paper there is a focus on price trends in the EU-15 (i.e. before accession in 2004 and 2007 of mostly transition countries) on one side, and consumers satisfaction with prices (and quality) of the fixed telephone service, on the other side. A similar study in this context has been conducted by Copenhagen Economics (2005) for the European Commission. In the present study, however, there is a use of different data sources in order to enlarge the dataset and increase the number of observations. Moreover, it is also investigated the impact on other related prices borne by consumers, such as monthly telephone subscription and connection charges. Furthermore, the REGREF indicators for market regulation are used, as proposed by the OECD. For customers' satisfaction the focus is on three waves of the Eurobarometer survey $(2000,2002,2004)$, while for prices and other industry features on Eurostat and ITU data.

The structure of the paper is the following one. The following section briefly reviews the empirical literature; Section 3 proposes a general theoretical framework; Section 4 presents data sources and some descriptive statistics, while Section 5 is about modelling price dynamics; Section 6 offers probit estimation of consumer satisfaction with prices and quality; the last section concludes with suggestions for further research and policy implications.

\section{Literature review}

Despite the large body of empirical literature on telecommunication and its changing institutional setting, relatively little attention has been paid to price determinants. 
$\mathrm{Li}$ and $\mathrm{Xu}$ (2004) use a large set of 177 countries over the period 1990-2001 to estimate the impact of privatization and competition in telecommunication with ITU and World Bank data. They find positive effects of privatization on output, productivity and resource allocation but their estimates show that full privatization increases both output and prices of local calls. They propose two possible explanations: a combination of strong network externalities and non competitive behaviour among existing operators, or an increase in service quality (not captured by data) that drive up the cost of phone calls. However, they employ only simple dummy variables to capture shifts in regulation. Moreover, they do not find a significant effect of competition on prices and a modest one in containing the adverse effect of privatization (interaction term).

Cave and Vogelsang (2003) point out that intermediate price can play an important role in promoting competition and influencing final prices, while Bauer (2003) finds no statistical evidence of price increase eventually determined by the substantial license fee paid by mobile operators.

In a recent paper Grzybowski (2008) examines, like in the present work, the impact of regulation on telecommunication prices estimating a reduced form model for European Union from 1998 to 2002. Regulation and cost factors (including technology) explain $94 \%$ of price variation and the former has a significant negative impact on incumbent retail price. Prices are taken from the study Teligen realized for the European Commission, and cover a period of four years only. As measures for regulation he uses several micro variables taken from the different EC Implementation Reports like carrier pre-selection, number portability and local loop unbundling, and a dummy for market liberalization. In a previous paper Grzibowski (2005) studied the mobile market estimating a reduced form model using panel data for the EU countries from 1998 to 2002 and showing the relationships between mobile and fixed telephony markets. Liberalization of fixed telephone has a negative impact on the prices for mobile services and a positive effect on the demand while competition enhancing measures like the introduction of number portability has a negative impact on mobile call prices.

Boylaud and Nicoletti (2001) estimate a panel with data on 23 OECD countries in 1991-97 and show that prospective competition (proxied by the number of years remaining to liberalization) and effective competition (proxied by the market share of new entrants) both reduce the price of all the telecommunication services but not clear evidence could be found concerning the effect of the ownership structure of the industry on performance and price. Edwards and Waverman (2006) study intermediate price in 15 European countries for few years (1997-2005) and find that public ownership increases interconnection prices while regulator's independence decreases them.

Estache, Goicochea, and Trujillo (2006), in a paper focused on the link between corruption and utilities reform, analyze a large sample of countries and find that privatization of incumbent telecom operator increases prices while establishing an independent regulatory authority decreases them.

Gasmi and Virto (2010) study fixed charges for telephone and cellular prices in 29 developing and 23 developed countries looking for the effect of different institutional governance and find that privatizations increase prices in developing countries while has no effect in developed economies. 
As compared with earlier literature, in this paper longer time series and more detailed information on regulatory reforms in the EU have been considered in the empirical analysis.

\section{Conceptual model}

This section presents an illustrative framework for the determination of telephony price equilibria under different reform patterns ${ }^{1}$. It is assumed that there is one homogeneous fixed telephony service and one price for it (instead of a bundle of services and a combination of time-based tariffs, subscription rates, connection charges, rental prices of equipments, etc $)^{2}$. The regulatory regimes that are going to be discussed are stylized as follows: first, a vertically integrated public monopoly; second, a privatized, but still vertically integrated monopoly, without any price regulation (except the constraint of no price discrimination across users); third, a price-cap regulation of the privatized monopoly; fourth, unbundling as a preliminary step to liberalization; fifth, a duopoly market, without price regulation; sixth, full market entry, as an extension of the previous case. In this setting, the main interest is to see how consumer's prices change following a reform, after assuming that demand is exogenous.

First, consider a telecom operator under a vertically integrated public monopoly, as it was common in the EU before mid 1980s (e.g. British Telecom, France Telecom, Telecom Italia, etc). The monopolist faces an exogenous linear demand curve for residential users, for a given per capita GDP:

$$
p^{P M}=a-b q .
$$

The representative consumer responds to changes of per capita GDP over time simply by a shift of their Marshallian demand. This effect is captured by changes of the intercept $a$. There are no substitution effects (e.g. with mobile telephony). The demand is sensitive, however, to a set of country features, including consumers' preferences. The public firm's returns to scale are assumed to be constant in each time period and for each country. This assumption reflects a combination of zero marginal costs of the fixed telephony network, i.e., the natural monopoly segment of the industry, and of positive constant average and marginal costs of operation and sales. In general, marginal cost $c$ of fixed telephony can be represented by a function of four variables (plus noise): population density, number of lines, technology change, and productivity per employee.

One assumes that the public firm's costs $c^{\mathrm{PM}}$ are higher than in a first best economy benchmark $c^{*}$, a value that can be inferred by engineering data, so that

$$
c^{P M}=c^{*}(1+\alpha)
$$

\footnotetext{
${ }^{1}$ See for details Ceriani \& Florio, 2011

${ }^{2}$ This assumption should be seen just a heuristic device to present a simple theoretical model. Further research would try to disentangle conceptual models for different policies, including wholesale/access pricing and whether it tends to have an impact on the interconnection between different types of services.
} 
For any given country and time, population density is given. The number of new switched lines, the speed of technology adoption (including investment and human capital accumulation) and productivity of the workforce (typically the number of switched lines per employee) may be partly hindered by lack of incentives of the management to minimize costs.

Moreover, the $\alpha$ parameter captures - for each country and time - both inefficiency because of lack of incentives to minimize costs by the managers, and rent extraction by policy makers (including a mark-up over costs, that generates profits for the Treasury) and by other stake-holders who actually control the firm (perhaps the trade unions).

After allowing for this social cost of public provision, the managers are instructed by their principal to maximize consumer's surplus, under strict budgetary constraint. Hence, the firm follows the traditional marginal cost rule for fixing price:

$$
p^{P M}=c^{P M}=c^{*}(1+\alpha) .
$$

A demand shift over time under this assumption has no impact on equilibrium price, as only quantity of telephone service provided will respond (through a change from $a_{f t}$ to $a_{f, t+1}$ for the same slope $b$ ). Prices, however, will respond to changes of $c^{*}$ (technology innovation, e.g. changes of switching technology, adoption of optical fibres, etc) and possibly of $\alpha$ (e.g. less harmful interference by government or trade unions, better management, release of investment constraints, decrease of the 'fiscal' mark-up). Over time the process results in lower $c_{f, t+1}{ }^{P M}$ and prices will tend to decrease, more or less slowly according to specific country and firm's features, following the two different drivers:

$$
\frac{\partial c^{*}}{\partial t}<0 ; \frac{\partial \alpha}{\partial t} \leq 0 \rightarrow \frac{\partial p^{P M}}{\partial t}<0
$$

Quantity of service provided and the consumer's surplus are:

$$
\begin{aligned}
& q^{P M}=\frac{a-c^{*}(1+\alpha)}{b} \\
& C S^{P M}=\frac{\left[\left(a-c^{*}(1+\alpha)\right)^{2}\right]}{2 b}
\end{aligned}
$$

Let us turn now to a different state of the world (time or country) where the government privatizes the public monopolist, without, however, imposing a pricecap or rate-of-return regulation. The only regulatory rule is that price discrimination is forbidden. Since the private owner has an incentive to minimize costs, one assumes now that the management is instructed by the new principal to wipe away any inefficiency and to maximize profits. As a result the quantity and price of service provided change respectively to:

$$
\begin{aligned}
& q^{U p r}=\left(a-c^{*}\right) / 2 b \\
& p^{U p r}=\left(a+c^{*}\right) / 2 .
\end{aligned}
$$


Here an increase of the demand for telephone services will raise prices and not just quantities, while a decrease of costs will decrease prices and increase quantities.

By comparison of the price of the public and of the unregulated private monopoly, the reform will decrease prices whenever the inefficiency of the former exceeds the allocative inefficiency of the latter. The indifference value of the initial inefficiency parameter is simply

$$
p^{U p r}=p^{P M} \rightarrow \alpha^{U p r, P M}=\left(a-c^{*}\right) / 2 c
$$

This is also exactly the value that makes the consumer's surplus the same in the two ownership règimes, being $\mathrm{CS}$ under private monopoly now:

$$
C S^{U p r}=\left(a-c^{*}\right)^{2} / 8 b
$$

In general, however, the indifference conditions between two regulatory regimes will be different for prices and for consumer's surplus, as shown below.

In another country or time, the government appoints a telecom regulator with the power to impose a price-cap to the privatized incumbent. The regulator perfectly knows the technology of the regulated firm, and picks up a price constraint sufficient to offer the private investor an 'adequate' profitability. Suppose that for any time period there is a simple mark-up $\beta$ over the first best (or minimum) marginal cost that is incentive compatible. The new quantity and price equilibrium is now:

$$
\begin{aligned}
& q^{R p r}=\left[a-c^{*}(1+\beta)\right] / 2 b \\
& p^{R p r}=c^{*}(1+\beta) .
\end{aligned}
$$

The optimal production plan of the telephone operator is exactly the same that under the unregulated regime. Moreover, price is not affected by the change of ownership plus regulation whenever $\beta=\alpha$.

Again, the inefficiency parameter of the public monopoly sets a threshold for price indifference after the reform. Moreover, and differently from the previous case, demand or technology shocks will not change the price. The adjustment is entirely through quantity, while the firm will earn more or less profits simply as a result of these adjustments given the mark-up (in fact, and in a RPI-x setting, $\beta$ will be gradually adjusted by the regulator for nominal price changes and available information on productivity increase).

Now consider a different reform arrangement, where the regulator imposes to the incumbent the ownership or legal separation of the network, as recently (September 2008) required by the European Parliament. This new reform is best seen as preparation to granting access to entrants. One may start with the simplest case, the establishment of a legal duopoly, as it existed in the UK in the 1980s, with BT as the incumbent and Mercury as the sole entrant. At the same time (and differently from the British example at that time) suppose that the price-cap is lifted.

The unbundling of the telephone network (an example is Openreach division of BT in recent years) has some administration and coordination costs. Moreover, both the incumbent and the entrant will face additional costs as compared with the 
vertically integrated monopoly arrangement, because of the increasing marginal costs of operations and sales, as mentioned above. It is described simply by

$$
C^{D}=c^{*}(1+\delta),
$$

where $\delta$ is the combined effect of the extra-costs of unbundling and loss of economies of scale. One may assume here that the extra-cost is entirely loaded to the entrant.

In order to see what happens to prices, one adopts here the Chamberlin (1948) 'small group' competition model. There is no possibility of collusion (the regulator is in charge of preventing this) or of strategic behaviour. The entrant assumes that a share of the market is left unexploited by the incumbent. Thus the entrant fixes its optimal quantity and price supply of the service based on the free segment of the demand curve. Price is clearly less than for the incumbent's segment, and because the telephone service is homogeneous, the incumbent must fix the price at the new lower level. Simple algebraic manipulation of the above conditions for the unregulated monopoly gives now ${ }^{3}$ :

$$
\begin{aligned}
& q^{D}=\left(a+c^{*}(3+2 \delta)\right) / 4 b \\
& p^{D}=\left(3 a+c^{*}(3-2 \delta)\right) / 4
\end{aligned}
$$

This regulatory mechanism can be seen as an alternative to price cap regulation, because the incumbent is forced to adopt the equilibrium price in the entrant's market, and to provide access to the network.

Thus it is possible to compute the $\beta$ value that the regulator in the previous case should use, if incentive-compatible, to mimic the role of duopolistic competition and to achieve price indifference in the two cases. It is also possible to see what is the value of the $\alpha$ parameter that makes the equilibrium price of an unregulated duopoly the same as the vertically integrated public monopoly. By construction of the model, it turns out that the two conditions are the same:

$$
\alpha^{P M, D}=\beta^{R p r, D}=\left(a-c^{*}(1+2 \delta)\right) / 4 .
$$

The response of the duopoly market prices and quantities to variations across countries or over time of the demand are again represented by shifts of the $\alpha$ parameter. Technological progress, investments, labour productivity, scale factors

${ }^{3}$ The starting point is: $p^{U p r}=\frac{a+c^{*}}{2}$ and $q^{U p r}=\frac{a-c^{*}}{2}$. For the entrant, the new demand and marginal revenue are: $p^{E, D}=\frac{a+c^{*}}{2}-b q$ and $p^{E, M R}=\frac{a+c^{*}}{2}-2 b q$. Given that $\mathrm{MR}=\mathrm{MC}$, then $\frac{a+c^{*}}{2}-2 b q=c^{*}(1+\delta)$, from which $q^{E}=\frac{a+c^{*}}{4 b}-\frac{c^{*}(1+\delta)}{2 b}$. The total demand $q^{D}=q^{E}+q^{U \operatorname{Pr}}=\frac{a+c^{*}}{4 b}-\frac{c^{*}(1+\delta)}{2 b}+\frac{a-c^{*}}{2 b}=\frac{a+c^{*}(3+2 \delta)}{4 b}$.

Equations (14) directly follows by substituting $q^{D}$ into the original demand function (1). 
are represented by a decrease of $c^{*}$. Hence, if in a given country $f$, the elasticity of telephone demand to GDP is 1, and real GDP increases by $g$ percent, and minimum costs decrease by $h$, the new price will simply be:

$$
p^{D}=\left(\left(a(1+g)+c^{*}(1-h)(3-2 \delta)\right)\right) / 4 .
$$

To study the impact on prices of market liberalization, one could add a second, third and so on entrant in the previous model. A straightforward approach is due to Cournot (1897), in his model with many competitors. After having unbundled the network, the regulator is now ready to offer a telephony license to any entrant. The total quantity of service supplied will now be $Q^{M E}=q_{1}+q_{2}+\ldots q_{j}+\ldots+q_{n}$. Because for a generic $j$-th firm profit maximization implies

$$
p+(\Delta p / \Delta q) q_{j}=c_{j}
$$

where the 1.h.s. is the marginal revenue, and r.h.s. is the marginal cost. Following Varian (1987), the second condition can be written as:

$$
p\left(1+(\Delta p / \Delta q)(Q / p)\left(q_{j} / Q\right)\right)=c_{j}
$$

By definition $(\Delta p / \Delta q)(Q / p)$ is the elasticity to price of the industry demand curve, $\varepsilon$, while $\left(q_{j} / Q\right)$ is the market share of the entrant, $s_{j}$. Using this notation, the above condition for profit maximization can be written:

$$
p\left(1-1 /\left(\varepsilon / s_{j}\right)\right)=c_{j}
$$

The $\varepsilon / s_{j}$ ratio can be interpreted as the elasticity of the demand curve faced by the single entrant. The smaller the market share, the more elastic the demand. In this way, when $s_{j}=1$ the unregulated monopoly market structure is back, while as the market share tends to zero, the condition is the one of pure competition: price equals marginal cost. The latter, however, are again not equal to minimum $\operatorname{cost} c^{*}$, because in a network industry as fixed telephony, after unbundling, each firm will face decreasing returns, not matched by the increasing return of the natural component. As in the previous duopoly case, there will be an inefficiency factor $\delta$, that is now an increasing function of the number of entrants, so that the marginal cost is:

$$
c_{n}=c^{*}\left(1+\delta_{n}\right)
$$

Equivalence between prices under public vertically integrated monopoly, regulated privatized monopoly, and market opening is now given by the simple condition $\alpha=\beta=\delta_{n}$.

To sum up: telephone prices, in this simple framework, can vary across countries and over time because of forces that push in different directions. The change of regulatory regime, from vertical integration, either under public or private ownership, to unbundling and limited market opening, will lower prices only for some combinations of the $\alpha, \beta, \delta$ parameters, but not for all of them. It is difficult 
to predict which of the above stylized arrangements will deliver lower prices to the consumer. When the vertically integrated public monopoly is very inefficient, even an unregulated private monopoly can lower prices. Price-cap regulation can mimic cost-plus inefficiency of the public firm or cost-plus a permitted mark up of an oligopoly. Market entry is an alternative to price regulation or public monopoly, but it needs costly access or network unbundling in some form, and cost duplications of several activities with increasing return to scale.

Thus, it seems important to disentangle the effects on prices of changes of regulatory regime from other determinants. In other words, prices can respond, as already seen, directly to changes of market structures and demand, to changes of costs indirectly induced by regulatory reforms, or to exogenous trends of some costs. The empirical analysis should disentangle, as far as possible, these components of telephone price variation over time and across countries.

\section{Data and descriptive statistics}

To answer the main question of the paper, two empirical analyses are proposed: an econometric analysis for the dynamics of prices of fixed telephone calls, and another one for subjective perception of the price and quality of the telecommunication services. In the first one the prices of fixed telephone calls are modelled in order to verify the impact of the reform process. The investigation concerns the 15 EU Countries for the period 1997-2003. Almost all the information concerning the telecommunication sector comes from the ITU World Telecommunication Indicators (2006) dataset. The database contains time series data, mainly collected from an annual questionnaire sent out by the Telecommunication Development Bureau (BDT) of ITU, for the years 1960, 1965, 1970 and annually from 1975-2005 for around 100 sets of telecommunication/ICT statistics covering telephone network size and dimension, mobile services, quality of services, traffic, staff, tariffs, revenue and investment. The price indicators for fixed telephone calls, instead, come from the Eurostat dataset, and distinguish between 10 minutes local, national and international calls ${ }^{4}$. Using these three measures for the prices of fixed telecom calls provides a wider inspection about the effects of the policy intervention to enhance the liberalization of the market. Monthly telephone connection charges have also been considered in that part of total costs supported by the final users of the service.

The REGREF regulatory dataset has been created by the OECD ${ }^{5}$. It collects information about indicators of privatization, liberalization and disintegration of services of general interest across the OECD countries for 18 years from 1975 to 2003. Regarding the telecommunications sector the database provides information about three dimensions: public ownership, entry regulation and market structure.

\footnotetext{
${ }^{4}$ In a previous version of the paper, the analysis was on the single indicator for the 3-minute fixed telephone local call (peak rate) collected by the ITU, mainly because of the long time series collected for the $15 \mathrm{EU}$ countries. The results, however, probably were not significant for an overall quantification of the reform process, in that considering the local calls price only could underestimate the impact of the liberalization policies.

${ }^{5}$ See Conway \& Nicoletti (2006) for further details.
} 
In particular, concerning the fixed telephone market, the following variables are considered:

-Public ownership: this series indicates the degree of public ownership in the industry. The variable is coded between 0 (private ownership) to 100 (public ownership) and is the percentage of shares in the $\mathrm{PTO}^{6}$ owned by government.

-Entry regulation: this series is an indicator of legal conditions of entry in the market and can assume three values only: 0 (free entry), 1 (oligopoly) and 2 (monopoly).

-Market Structure: this variable indicates the market share of new entrants and it is coded from 0 to 100. In the empirical analysis, however, in order to simplify the interpretation of the results, the indicator has been recoded such that 100 becomes the situation of complete absence of liberalization.

The REGREF database provides also a summing index, called Aggregate Telecommunications Regulatory Indicator (ATRI), that is a weighted mean of the three different time series. The time series starts in 1975 and ends in 2003. A decrease in the aggregate indicator represents an increase in the liberalization process.

Among the explanatory variables, in the regression models discussed in the following section the number of fixed telecom lines (lines), the amount of investments in the telecommunication sector (investment), the number if ISDN channels (isdn channels) as a measure for the technological progress, the population density (density), and the number of subscribers in the mobile telephone sector (mob subscribers) are all included. A complete description of the data is reported in Table 1. Table 2 and Table 3 report some descriptive statistics and the correlations between the variables.

Table 1-3 about here

The second part of the empirical analysis, instead, concentrates on the relations between consumers' subjective satisfaction, prices of the telecommunication services, and reforms. Consumers' subjective satisfaction is measured in the Eurobarometer dataset, which collects information about approximately 1,000 people in each European country in 2000, 2002 and 2004. The number of observations, thus, consists of about 15.000 individuals for each wave, for a total of more than 45.000 observations in the regression analysis. The satisfaction towards telecom services is coded with ordinal variables and, analogously to Eurobarometer (2005), consumers' satisfaction about prices and quality is dichotomized into "satisfied" $(=1)$ and "not satisfied" $(=0)$. In particular, concerning the price of the service, "satisfied" collects all the individuals declaring the price is "fair", while "not satisfied" those declaring the price in "unfair" or "excessive". Concerning the quality of the service, the questionnaire indicates four categories, "very bad", "fairly bad", "fairly good" and "very good". Most of the respondents have positive impressions about the quality, while only few of them respond negatively. In order to increase the variability of the phenomenon, "satisfied" collects those responding with "very good", while "not satisfied" all the others. This is summarized in Table 4 and Table 5.

\footnotetext{
${ }^{6}$ Public telecommunications operator.
} 
Table 4 and 5 about here

To account for the large differences in the elements appearing in the sample, one has also to consider specific individual effects such as gender, age, marital status, education, occupation, political orientation. Moreover, in order to account for the differences among countries, country specific variables are considered, such as: real Gross Domestic Product growth $(G D P)$, Consumer Price Index $(C P I)$, inflation rate $(\triangle C P I)$, Per capita GDP $(p c G D P)$, Employment growth $(\triangle e m p)$, population density, GINI index. As price and policy indicators, the same variables described above are used.

\section{Explaining telecommunication price dynamics}

The conceptual model presented in Section 3 can be translated in a standard demand-supply structural model augmented with regulatory variables. The general form of the model, taking inverse functions is the following one:

$$
\begin{aligned}
& P_{d t}=P_{d}\left(Q_{n t}, D_{j t}\right) \\
& P_{s t}=P_{s}\left(Q_{n t}, S_{z t}, r_{i t}\right)
\end{aligned}
$$

where $P_{d t}$, and $P_{s t}$ are demand and supply prices, $Q_{n t}$ is the quantity of the n-th service demanded and supplied, $D_{j t}$ is a vector of demand shifters, $S_{z t}$ is a vector of cost shifters, and $r_{i t}$ is a vector of regulatory variables. Examples of demand shifters are typically GDP per capita, or the demand for substitute goods, such as mobile phone services. Examples of supply shifters are technology variables, such as ISDN channels, along with the regulatory variables, related to ownership and entry regulation. It is assumed that regulatory variables are exogenous policy decisions. For examples, it seems realistic, and supported by country data and histories that the decision to privatize the PTO is unrelated to the previous relatively high or low price level of telecom services. The resulting price, from equations 21-22, is the short-term equilibrium price. Given this simple frame, similarly to previous estimates cited in earlier literature, one can directly estimate a reduced form empirical equation, in order to see how the variables influence the short-term price equilibria, as done by Grzybowski (2008), Edwards and Waverman (2006), Li and Xu (2004), Gasmi and Virto (2010) ${ }^{7}$. Because of data limitation and more limited objective, the estimation of a structural model, however, is beyond the scope of this paper.

Hence, the empirical analysis is based on the specification and estimation of reduced equations for local, international and national prices, and connection charges. For each of the dependent variables, there is a regression model that includes, among the explanatory variables, aggregate or detailed measures of the level of privatization and market opening of the sector. Given the structure of the data, the empirical analysis is based on panel data techniques, with country fixed

\footnotetext{
${ }^{7}$ See section 2. See also Kaplan (2000) or Reiss \& Wolak (2007) for a detailed discussion on the relationship between structural and reduced form in economic models.
} 
effects accounting for all the variability not explicitly modelled by the regressors. The general specification is the following

$$
p_{i t}=\beta_{0}+\beta_{0 i}+\beta_{1}{ }^{\prime} x_{i t}+\beta_{2}{ }^{\prime} r_{i t}+\varepsilon_{i t}
$$

where $\beta_{0}$ and $\beta_{0 i}$ are the constant term and the country fixed effects respectively, $\beta_{1}$ is the vector of parameters associated to the regressors $x_{i t}$, while $\beta_{2}$ is the vector of parameters associated to the regulatory variables $r_{i t}$, i.e. alternatively the Aggregate Telecommunications Regulatory Indicator (ATRI), or the Public ownership, Entry regulation and Market structure. For each dependent variable four alternative specifications are proposed, which jointly represent the dynamics of prices in the fixed telephony sector ${ }^{8}$.

The error term $\varepsilon_{i t}$ is expected to follow the standard hypotheses for the fixed effects models, i.e. null conditional expected value and homoskedasticity. However, the first hypothesis might be violated since some explanatory variables used in the regressions may be argued to be endogenous, such as investments, the number of lines, and the levels of the technological progress captured by the number of isdn channels. In order to control for the endogeneity of these variables, as far as possible, an instrumental variables fixed effects approach has been used. The instruments, due to the restricted amount of information from institutional data bases, are found by taking lagged values of all the variables used in the regressions, providing that there is no autocorrelation of the error terms. The Sargan J-test statistic and Arellano-Bond test for autocorrelation are provided for each regression in order to check for the goodness of such instruments. The null hypothesis of exogenous instruments for the Sargan J-test, and the absence of autocorrelation can never be rejected by the data.

\subsection{International calls prices}

The results of the estimation procedures when the dependent variable is the indicator of the price for international calls are reported in Table 6. As mentioned before, four alternative specifications are reported. Columns A and B introduce the aggregate indicator ATRI for the liberalization policy interventions. The two specifications differ according to the presence, in column $\mathrm{B}$, of the number of subscribers in the mobile telephony sector, mob subscribers. The third and fourth specifications, reported in column $\mathrm{C}$ and $\mathrm{D}$, use the same regressors as A and B, but considering the disaggregated reform indicators, Entry regulation, Public ownership, and Market structure.

When the aggregate indicator of market opening is included, from the results in column A it emerges that the coefficient is significant and positive, indicating that an increase in the liberalization process induces a reduction in the prices of international calls. The result, however, becomes less evident when controlling for the diffusion of mobile telephony, measured as the number of mobile subscribers.

\footnotetext{
${ }^{8}$ In order to test for the appropriateness of the fixed effect panel data model, for all regressions, a random effect model has been estimated and an Hausman specification test performed to compare the two. The test, reported in the results in Table 6-9, is always significant, suggesting to reject the more efficient, but in this case inconsistent, random effect model.
} 
In this second case, in fact, the coefficient continues to be positive, but becomes not significantly different from zero. A very similar pattern does appear when the focus moves on the distinct aspects of liberalization. In particular, in regression $\mathrm{C}$, the only significant intervention policy concerns the market structure, indicating that a more liberalized market acts at reducing the levels of prices. This evidence, as before, disappears when introducing the number of mobile subscribers. The mobile sector, thus, clearly plays the role of competitor and the rapid diffusion of the latter contributes at reducing the prices of fixed telephone calls. The prices of international calls are also reduced with investments in the telecom sector, while the technological development seems to play a limited role.

Table 6 about here

\subsection{National calls prices}

Table 7 reports the results for the explanations of the national calls prices. The results highlight a situation very similar to what discussed for the international calls prices. Among the regulatory variables, the only one that matters is the Market structure, and even in this case, with an impact that reduces (but is still significant) when controlling for the diffusion of the mobile telephony market. The amount of investment in the telecom sector is extremely important in explaining the level of national calls prices, as well as the technological progress.

Table 7 about here

\subsection{Local calls prices}

The results for the dynamics of local calls prices are shown in Table 8. As in the previous cases, column A and B show the aggregate regulatory indicator, while column $\mathrm{C}$ and $\mathrm{D}$ include the detailed aspects of the regulator interventions. The coefficient of the aggregate indicator is positive and significantly different from zero, indicating the importance of the market liberalization for reducing the price. This result does not substantially change when controlling for the mobile market diffusion.

When the disaggregated indicators are included, Market structure and Public ownership are significant and with the expected positive sign. Moreover, this result is robust to the two alternative specifications in $C$ and $D$, i.e., with and without taking into account the role of the mobile telephone sector. The policies of privatization and liberalization, together contributed at reducing the prices of local calls ${ }^{9}$. The number of mobile subscribers, even in this case, plays a relevant role, though less important than for international and national calls prices.

Table 8 about here

\footnotetext{
${ }^{9}$ The legal conditions for joining the market, never significant in the previous cases, here becomes slightly significant but with the unexpected, and of difficult interpretation, negative sign. The level of investments is never significant, while technological progress is significant but, with a surprising positive coefficient.
} 


\subsection{Connection charges}

The last model considers the dynamics of the connection charges, and the results are provided in Table 9. The aggregate index is positive and significant only when excluding the mobile diffusion indicator. The number of fixed telephone lines is always significant and positive, as well as the technological progress, which contributes at reducing this component of the fixed telephone prices. A surprising and remarkable result, instead, concerns the role played by the Entry regulation variable, which enters negatively in the explanation of the connection charges. More precisely, moving towards less restrictive legal conditions for entry into the fixed telephone market leads to an increase in the connection charges. In other words, the gains obtained in the decreasing levels of price calls, are partially compensated by the increasing of the connection charges.

Table 9 about here

\section{Consumers' satisfaction with telecom prices}

The previous section analyzed whether an objective measure of a key element of consumers' welfare, such as the price they pay, is influenced by regulatory variables. This section extends the analysis by investigating whether subjective measures of satisfaction with telecommunication prices and quality are influenced by market reforms and prices. There are two reasons for looking into subjective evidence: perceptions are important per se, because they can influence government and regulators decisions; moreover, micro-information available to the individual user can be more revealing than the aggregate statistics used in the previous section, e.g. because of price discrimination across types of users.

As one does not know the exact level of individual satisfaction, $S_{i}^{*}$, for each service, it is assumed that satisfaction is generated by a latent variable model:

$$
S_{i}^{*}=X_{i}^{\prime} \beta+e_{i}
$$

where $i=1 . . N$ for a sample of $N$ individuals, and $X_{i}$ includes a set of individual characteristics $\left(x_{i j t}\right)$, macroeconomic variables $\left(z_{j t}\right)$, and regulatory indicators for entry regulation, public ownership, and market structure and vertical integration $\left(r_{j t}\right)$. Telecommunication market prices $\left(p_{j t}\right)$ are also included among independent variables to verify whether subjective satisfaction depends on actual prices and whether the relationship between subjective satisfaction and regulatory variables is at all driven by the relationship between regulatory variables and market prices. Finally, $e_{i}$ is a continuously distributed variable independent from $X_{i}$, and accounts for unobserved heterogeneity. As $S_{i}^{*}$ is latent, for each individual $i$, one can only observe

$$
S_{i}=1\left(S_{i}^{*}>0\right)
$$

where 1(.) is equal to 1 if the argument is true, and equal to 0 otherwise. Assuming that $e_{i}$ is distributed as a standard normal the probit model will be: 
$P(S=1 \mid X)=P\left(S^{*}>0 \mid X\right)=P(e>-X \beta \mid X)=1-\Phi(-X \beta)=\Phi(X \beta)$

or, more explicitly,

$$
P\left(S_{i j t}=1 \mid x_{i j t}, z_{j t}, r_{j t}, p_{j t}\right)=\Phi\left(\beta_{0}+\beta_{0 j}+\beta_{0 t}+\beta_{1}{ }^{\prime} x_{i j t}+\beta_{2}{ }^{\prime} z_{j t}+\beta_{3}{ }^{\prime} r_{j t}+\beta_{4}{ }^{\prime} p_{j t}\right)
$$

where $\Phi$ is the standard normal cumulative distribution function, and $\beta_{0 \mathrm{j}}$ and $\beta_{0 \mathrm{t}}$ are country and year fixed effects, respectively. In Table 10 marginal effects for price (columns A and B) and quality (columns $\mathrm{C}$ and D) satisfaction are reported $^{10}$.

Concerning the consumers' satisfaction about prices, the regulation variables appear to be important in explaining the probability of being satisfied. All policy indicators in fact, enter significantly, but the entry regulation variable shows a surprising positive sign ${ }^{11}$. This last result can be explained by observing that over the three years, only Portugal and Greece for the two years 2000 and 2002 (i.e. only 1002 over the total amount of 47284 observations) present values different from 0 , which indicates free entry in the trunk telephony market. The other two policy indicators, market structure and public ownership, enter with negative signs and are statistically significant.

The effect of price indicators in the explanation of consumers' satisfaction is significant and negative, as expected, for national and international calls prices. The price of local calls have an ambiguous impact: it enters significantly with a positive sign in both specifications. The country fixed effects are extremely significant in almost all cases, pointing to national features not captured by the regulatory variables and the other controls. Finally, as 2000 is the base year, it is difficult to find evidence towards a significant increase of consumers' satisfaction about the price of the telephony service.

The same model structure has been used for investigating the satisfaction about the quality of the service ${ }^{12}$. Results, in terms of marginal effects, are reported in columns C and D of Table 10. Similarly with the previous case, Entry regulation enters significantly with a positive sign, indicating that legal conditions towards competition has a negative impact on the perception of higher quality. An opposite effect is provided by the market structure indicator, that enters significantly and with negative sign, indicating a higher perception of the quality of the service as the market becomes more open. Privatization does not offer a significant contribution in increasing the quality perception of the service.

\footnotetext{
${ }^{10}$ As a robustness check, an ordered probit model considering all categories of satisfaction reported in the data has also been estimated. The results, however, especially for the coefficients associated to the regulatory variables, confirm that the loss of information coming from the dichotomization approximation does not alter the final message, gaining, however, in terms of simplicity of presentation and interpretation.

${ }^{11}$ See footnote 6.

${ }^{12}$ Consider this as a complement to the analysis of prices, as one could argue that higher prices may reflect a better service.
} 
The impact of the price variables is in the same direction as for the perception of prices. Local calls prices, and marginally the national ones, enter significantly but with positive sign. As before, thus, an increase of prices is interpreted by the customers as an increase in the quality of the service. On the contrary, for the international calls prices, the effect is negative.

Country fixed effects are very limited, indicating not substantial differences among the perception of satisfaction about the quality of the telecom services across the 15 EU Countries investigated.

Table 10 about here

\section{Concluding remarks}

Although the empirical analysis of fixed telephony prices is severely constrained by data limitations, it is entirely new. It has a wider scope than previous empirical work at EU level, either by the European Commission, the OECD or by national regulatory bodies. The analysis is based on the best evidence available to any researcher from official sources, such as Eurostat, Eurobarometer, OECD, ITU. The findings suggest that ownership change, from public to private, plays no role or a very limited one in explaining prices of international, national, local calls, connection charges. Thus, one key item of the reforms, privatization of the telecom incumbent, does not seem to be clearly supported by empirical evidence. The market share of entrants seems to play a more positive role, as one would expect in a more competitive environment, but the result is not very strong. The indicator for entry regulation has very limited explanatory power (or even has the "wrong" sign).

Overall, it seems that technology and demand factors, combined with unidentified country features, have much more explanatory power than any of the regulatory variables.

The results are not to be interpreted as an outright rejection of the reforms. Perhaps the OECD regulatory indicators fail to capture the subtle details of the reforms, but the Market Opening Milestones data used by Copenhagen Economics (2005a; 2005b) in an important study commissioned and frequently cited by the European Commission (Commission of the European Community, 2007a; 2007b) do not seem to add much to the OECD indicators. Future research should try to expand the empirical analysis by type of services, technology, demand variables, and better regulatory variables.

Having said this, up to now it would be less than prudent to state that the telecommunication reform experiment in the EU is supported by clear empirical evidence, at least for fixed telephony, of substantial benefits for the consumers across all countries. It is probably too early to discern policy implications from these findings, but two of them may be suggested for future investigation.

While being prudent in the interpretation, given data limitation, it seems that in some countries and under some circumstances public ownership of at least some part of the industry cannot be dismissed. There is some evidence that the market 
impact of competition does not seem to be affected by public ownership. This finding should be considered in the recent debates in the EU about who should own the main telecom networks. Should ownership separation of the network be implemented, public ownership of it is still an option to be considered. Moreover, if the network is not going to be separated from the incumbent, a public stake into the incumbent is an alternative option to be considered as well.

It seems that there is still wide scope for the EU governments to think about their active role in the design of a telecommunication policy. Consumers' subjective satisfaction broadly reflects the objective evidence, and this is also of interest for policy-makers. 


\section{REFERENCES}

Alesina, A., Ardagna, S., Nicoletti, G., \& Schiantarelli, F. (2005). Regulation and investment. Journal of the European Economic Association, 3 (4), 791-825.

Bauer, J M .(2003). Impact of license fees on the prices of mobile voice service. Telecommunications Policy, 27 (5-6), 417-434.

Boylaud, O., \& Nicoletti, G. (2001). Regulation, market structure and performance in telecommunications. OECD Economic Studies, 32(1), 99-142

Cave, M., \& Vogelsang, I. (2003). How access pricing and entry interact. Telecommunication Policy, 27 (10-11), 717-727.

Ceriani, L., \& Florio, M. (2011). Consumer surplus and the reform of network industries: a primer. Journal of Economics, 102(2), 111-122.

Chamberlin, E.H. (1948). An experimental imperfect market. Journal of Political Economy, 56(2), 95-108.

Commission of the European Community. (2007a). European electronic communication regulation and markets (12 ${ }^{\text {th }}$ Report), COM(2007)155. Retrieved from

http://ec.europa.eu/information_society/policy/ecomm/library/communications_re ports/annualreports/12threport/index_en.htm

Commission of the European Community. (2007b). Evaluation of the performance of network industries providing services of general economic interest (2006 report), Commission staff working paper, preliminary draft, Brussels. Retrieved from http://ec.europa.eu/internal market/economicreports/docs/2006/sec20071024-annex en.pdf

Conway, P., \& Nicoletti, G. (2006). Product market regulation in nonmanufacturing sectors in OECD countries: Measurement and highlights. OECD Economics Department Working Paper, 530. Retrieved from http://www.oecd.org/officialdocuments/displaydocumentpdf/?cote=eco/wkp(2006 $\underline{58 \& \text { doclanguage }=\text { en }}$

Copenhagen Economics. (2005a). Market opening in network industries (Final Report). DG Internal Market, European Commission, mimeo, Brussels. Retrieved from http://ec.europa.eu/internal_market/economicreports/docs/2005/part i final_report en.pdf

Copenhagen Economics. (2005b). Market opening in network industries: Sectoral analysis. DG Internal Market, European Commission, mimeo, Brussels. Retrieved from http://www.copenhageneconomics.com/Publications/Postal-services.aspx 
Cournot, A. (1897). Researches into the Mathematical Principles of the Theory of Wealth. New York, NY: The Macmillan Company.

Edwards, G., \& Waverman, L. (2006). The effects of public ownership and regulatory independence on regulatory outcomes. Journal of Regulatory Economics, 29(1), 23-67.

Estache A., Goicoechea A., \& Trujillo L. (2006). Utilities reform and corruption in developing countries. World Bank Policy Research Working Paper 4081. Retrieved from http://wwwwds.worldbank.org/external/default/WDSContentServer/IW3P/IB/2006/12/06/000 016406_20061206151405/Rendered/PDF/wps4081.pdf

Eurobarometer. (2005). The people of Europe and services of general interest (Report 219). Retrieved from http://ec.europa.eu/public_opinion/archives/ebs/ebs_219_report_en.pdf

Gasmi, F., \&.Virto, L. (2010). The determinants and impact of telecommunications reforms in developing countries. Journal of Development Economics, 93(2), 275-86.

Grzybowski, L. (2008). The impact of regulation on the retail price in fixed line telephony across European Union. Telecommunication Policy, 32(2), 131-144.

Grzybowski, L. (2005). Regulation of mobile telephony across the European Union: an empirical analysis. Journal of Regulatory Economics, 28(1), 47-67.

Kaplan, D. (2000). Structural equation modeling: Foundations and extentions, advanced quantitative techniques in the social sciences series. Thousand Oaks, CA: Sage Publications.

Li, W., \& Xu, L. (2004). The impact of privatization and competition in the telecommunications sector around the world. Journal of Law and Economics, 47(2), 395-430.

Newbery, D. (2000). Privatization, Restructuring and Regulation of Network Utilities. Cambridge, MA: The MIT Press.

Reiss, P. C., \& Wolak, F. (2007). Structural econometric modeling: Rationales and examples from industrial organization. Handbook of Econometrics volume 6A (pp 4277-4415. Amsterdam, NL: Elsevier.

Varian, H. R. (1987). Intermediate microeconomics. A modern approach. New York, NY: W.W. Norton \& Company, Inc. 


\section{TABLES}

Table 1: Description of the variables used in the regressions for the dynamics of prices

Variable

price international Price of international calls - PPP adjusted (log)

price

national

price

local

connection charge

ATRI

Entry regulation

Public ownership

Market structure

Lines

Investment

Isdn

Channels

Mob subscribers
Price of national calls - PPP adjusted (log)

Price of local calls - PPP adjusted (log)

Connection charge - PPP adjusted (log)

Aggregate Telecommunications Regulatory Indicator (REGREF - log)

is a an indicator of legal conditions of entry in the market and can assume three values only: 0 (free entry), 1 (oligopoly) and 2 (monopoly) (REGREF). percentage of shares in the PTO owned by government: it is coded between 0 (private ownership) to 100 (public ownership) (REGREF -log).

(100- market share of new entrants): it is coded from 0 to 100 (REGREF $\log )$

number of fixed telecom lines/population (ITU - log)

amount of investment in the telecommunication sector/number of lines (ITU - $\log )$

number if ISDN channels/number of lines (ITU - log)

number of subscribers in the mobile telephone sector/pop (ITU - log) 
Table 2: Mean (above) and standard deviation (below) for the variables in regressions for the dynamics of prices (the variables are not expressed in log terms)

\begin{tabular}{|c|c|c|c|c|c|c|c|c|c|}
\hline & $\begin{array}{c}\text { price } \\
\text { international } \\
\text { (PPP adjusted } \\
\text { - Euro) }\end{array}$ & $\begin{array}{c}\text { price } \\
\text { national } \\
\text { (PPP } \\
\text { adjusted } \\
\text { - Euro) }\end{array}$ & $\begin{array}{c}\text { price } \\
\text { local } \\
\text { (PPP } \\
\text { adjusted } \\
\text { - Euro) }\end{array}$ & $\begin{array}{l}\text { connection } \\
\text { charge } \\
\text { (PPP djusted } \\
\text { - Euro) }\end{array}$ & lines & Investment & $\begin{array}{c}\text { isdn } \\
\text { channels }\end{array}$ & $\begin{array}{c}\text { Mob } \\
\text { subscribers }\end{array}$ & density \\
\hline \multirow[t]{2}{*}{ Austria } & 0.220 & 0.087 & 0.042 & 109.094 & 0.492 & 2.842 & 0.207 & 0.609 & 95.822 \\
\hline & 0.080 & 0.049 & 0.009 & 14.597 & 0.010 & 0.897 & 0.096 & 0.294 & 0.795 \\
\hline \multirow[t]{2}{*}{ Belgium } & 0.190 & 0.066 & 0.033 & 67.689 & 0.481 & 2.132 & 0.175 & 0.498 & 336.767 \\
\hline & 0.098 & 0.030 & 0.001 & 6.866 & 0.012 & 0.588 & 0.068 & 0.305 & 2.473 \\
\hline \multirow[t]{2}{*}{ Denmark } & 0.173 & 0.036 & 0.026 & 134.797 & 0.682 & 2.469 & 0.200 & 0.603 & 123.811 \\
\hline & 0.070 & 0.016 & 0.003 & 19.423 & 0.032 & 0.495 & 0.091 & 0.234 & 1.003 \\
\hline \multirow[t]{2}{*}{ Finland } & 0.249 & 0.056 & 0.014 & 208.881 & 0.538 & 2.636 & 0.192 & 0.701 & 15.373 \\
\hline & 0.059 & 0.001 & 0.000 & 139.863 & 0.023 & 0.283 & 0.090 & 0.177 & 0.078 \\
\hline \multirow[t]{2}{*}{ France } & 0.149 & 0.070 & 0.027 & 47.561 & 0.576 & 1.807 & 0.109 & 0.445 & 107.856 \\
\hline & 0.068 & 0.015 & 0.002 & 4.794 & 0.006 & 0.216 & 0.033 & 0.234 & 1.175 \\
\hline \multirow[t]{2}{*}{ Germany } & 0.126 & 0.086 & 0.029 & 47.839 & 0.608 & 1.629 & 0.341 & 0.475 & 230.490 \\
\hline & 0.093 & 0.040 & 0.001 & 7.690 & 0.041 & 0.402 & 0.123 & 0.282 & 0.602 \\
\hline \multirow[t]{2}{*}{ Greece } & 0.165 & 0.081 & 0.014 & 56.141 & 0.536 & 1.603 & 0.070 & 0.513 & 81.621 \\
\hline & 0.071 & 0.046 & 0.004 & 48.200 & 0.019 & 0.747 & 0.069 & 0.301 & 2.620 \\
\hline \multirow[t]{2}{*}{ Ireland } & 0.126 & 0.069 & 0.032 & 141.574 & 0.470 & 2.242 & 0.124 & 0.560 & 54.163 \\
\hline & 0.046 & 0.030 & 0.005 & 36.883 & 0.028 & 0.802 & 0.064 & 0.280 & 1.664 \\
\hline \multirow[t]{2}{*}{ Italy } & 0.152 & 0.073 & 0.015 & 133.108 & 0.464 & 2.344 & 0.146 & 0.664 & 190.521 \\
\hline & 0.078 & 0.021 & 0.000 & 21.354 & 0.012 & 0.380 & 0.075 & 0.307 & 1.667 \\
\hline \multirow[t]{2}{*}{ Luxemburg } & 0.136 & & 0.022 & 65.313 & 0.577 & 3.006 & 0.464 & 0.689 & 168.530 \\
\hline & 0.101 & & 0.003 & 14.646 & 0.023 & 0.752 & 0.241 & 0.392 & 4.129 \\
\hline \multirow[t]{2}{*}{ Netherlands } & 0.104 & 0.037 & 0.020 & 90.837 & 0.552 & 2.414 & 0.309 & 0.534 & 384.751 \\
\hline & 0.114 & 0.014 & 0.002 & 37.392 & 0.057 & 0.658 & 0.152 & 0.285 & 5.587 \\
\hline \multirow[t]{2}{*}{ Portugal } & 0.174 & 0.074 & 0.017 & 75.806 & 0.417 & 3.303 & 0.127 & 0.593 & 110.054 \\
\hline & 0.084 & 0.036 & 0.001 & 11.163 & 0.010 & 0.973 & 0.056 & 0.294 & 2.458 \\
\hline \multirow[t]{2}{*}{ Spain } & 0.162 & 0.095 & 0.017 & 123.940 & 0.416 & 2.506 & 0.095 & 0.522 & 80.703 \\
\hline & 0.071 & 0.040 & 0.003 & 33.792 & 0.011 & 1.144 & 0.064 & 0.310 & 2.028 \\
\hline \multirow[t]{2}{*}{ Sweden } & 0.122 & 0.029 & 0.019 & 127.700 & 0.734 & 2.023 & 0.113 & 0.685 & 19.771 \\
\hline & 0.095 & 0.015 & 0.001 & & 0.018 & 1.017 & 0.051 & 0.228 & 0.109 \\
\hline \multirow[t]{2}{*}{ UK } & 0.132 & 0.050 & 0.036 & 148.917 & 0.568 & 3.727 & 0.093 & 0.586 & 244.759 \\
\hline & 0.026 & 0.009 & 0.003 & 26.269 & 0.016 & 0.593 & 0.037 & 0.300 & 1.560 \\
\hline \multirow[t]{2}{*}{ Total } & 0.159 & 0.065 & 0.024 & 104.167 & 0.541 & 2.446 & 0.185 & 0.578 & 149.666 \\
\hline & 0.083 & 0.034 & 0.009 & 62.591 & 0.090 & 0.884 & 0.143 & 0.277 & 106.414 \\
\hline
\end{tabular}


Table 3: correlations among the variables used in the regressions for the dynamics of prices

\begin{tabular}{|c|c|c|c|c|c|c|c|c|c|c|c|c|c|}
\hline & Price international & $\begin{array}{c}\text { price } \\
\text { national }\end{array}$ & $\begin{array}{l}\text { price } \\
\text { local }\end{array}$ & $\begin{array}{l}\text { connection } \\
\text { charge }\end{array}$ & ATRI & $\begin{array}{l}\text { Entry } \\
\text { regulation }\end{array}$ & $\begin{array}{c}\text { Public } \\
\text { ownership }\end{array}$ & $\begin{array}{c}\text { Market } \\
\text { structure }\end{array}$ & lines & Investment & $\begin{array}{c}\text { Isdn } \\
\text { channels }\end{array}$ & $\begin{array}{c}\text { Mob } \\
\text { subscribers }\end{array}$ & Density \\
\hline $\begin{array}{l}\text { price } \\
\text { international }\end{array}$ & 1 & & & & & & & & & & & & \\
\hline $\begin{array}{l}\text { price } \\
\text { national }\end{array}$ & $0.713^{*}$ & 1 & & & & & & & & & & & \\
\hline $\begin{array}{l}\text { price } \\
\text { local }\end{array}$ & 0.086 & 0.060 & 1 & & & & & & & & & & \\
\hline $\begin{array}{l}\text { connection } \\
\text { charge }\end{array}$ & $0.392 *$ & 0.078 & 0.100 & 1 & & & & & & & & & \\
\hline ATRI & $0.423^{*}$ & $0.531^{*}$ & -0.035 & -0.078 & 1 & & & & & & & & \\
\hline $\begin{array}{l}\text { Entry } \\
\text { regulation }\end{array}$ & $0.483 *$ & $0.615^{*}$ & -0.051 & -0.088 & $0.890 *$ & 1 & & & & & & & \\
\hline $\begin{array}{l}\text { Public } \\
\text { ownership }\end{array}$ & 0.044 & 0.110 & -0.055 & $-0.215^{*}$ & $0.760 *$ & $0.523 *$ & 1 & & & & & & \\
\hline $\begin{array}{l}\text { Market } \\
\text { structure }\end{array}$ & 0.100 & $0.368^{*}$ & 0.059 & $-0.306 *$ & $0.707 *$ & $0.692 *$ & $0.319 *$ & 1 & & & & & \\
\hline Lines & $-0.171^{*}$ & $-0.411 *$ & 0.153 & -0.109 & $-0.425^{*}$ & $-0.476^{*}$ & $-0.225 *$ & $-0.336^{*}$ & 1 & & & & \\
\hline Investment & 0.050 & -0.045 & 0.162 & $0.171 *$ & $-0.350 *$ & $-0.186 *$ & $-0.238 *$ & $-0.246^{*}$ & -0.091 & 1 & & & \\
\hline $\begin{array}{l}\text { Isdn } \\
\text { Channels }\end{array}$ & $-0.585^{*}$ & $-0.550 *$ & 0.170 & $-0.338 *$ & $-0.705 *$ & $-0.683 *$ & $-0.428 *$ & $-0.506^{*}$ & $0.578^{*}$ & $0.1956^{*}$ & 1 & & \\
\hline $\begin{array}{l}\text { Mob } \\
\text { subscribers }\end{array}$ & $-0.221 *$ & $-0.487 *$ & -0.115 & -0.050 & $-0.550 *$ & $-0.563 *$ & $-0.320 *$ & $-0.410^{*}$ & $0.704^{*}$ & $0.3173^{*}$ & $0.748 *$ & 1 & \\
\hline Density & $-0.193^{*}$ & 0.047 & $0.332 *$ & $-0.365^{*}$ & -0.060 & 0.044 & -0.083 & $0.159 *$ & -0.071 & 0.0828 & $0.105^{*}$ & $-0.107 *$ & 1 \\
\hline
\end{tabular}


Table 4: Satisfaction about prices and quality of the telecom services

\begin{tabular}{|ccc|ccc|}
\hline \multicolumn{3}{|c|}{ Price } & \multicolumn{3}{|c|}{ Quality } \\
\cline { 1 - 2 } excessive & 3,844 & \multirow{2}{*}{ not satisfied } & very bad & 302 & \\
Unfair & 12,921 & & \multirow{2}{*}{ fairly bad } & 1,914 & not satisfied \\
fairly good & 23,266 & \\
Fair & \multirow{2}{*}{25,056} & satisfied & very good & 16,774 & satisfied \\
\hline
\end{tabular}

Table 5: Distribution of consumer satisfaction across countries

\begin{tabular}{|c|c|c|c|c|c|c|}
\hline Country & n. obs & $\begin{array}{l}\text { Price } \\
\text { satisfied }\end{array}$ & $\%$ & n. obs & $\begin{array}{l}\text { Quality } \\
\text { satisfied }\end{array}$ & $\%$ \\
\hline UK & 3641 & 2819 & 77.4 & 3711 & 1733 & 46.7 \\
\hline Austria & 2425 & 1502 & 61.9 & 2422 & 1199 & 49.5 \\
\hline Belgium & 2712 & 1490 & 54.9 & 2726 & 1183 & 43.4 \\
\hline Denmark & 2782 & 2081 & 74.8 & 2824 & 1647 & 58.3 \\
\hline Finland & 2527 & 1520 & 60.2 & 2543 & 1038 & 40.8 \\
\hline France & 2710 & 1478 & 54.5 & 2745 & 923 & 33.6 \\
\hline Germany & 4962 & 3519 & 70.9 & 4969 & 1518 & 30.5 \\
\hline Greece & 2859 & 1181 & 41.3 & 2856 & 733 & 25.7 \\
\hline Ireland & 2549 & 1689 & 66.3 & 2635 & 1552 & 58.9 \\
\hline Italy & 2593 & 805 & 31.0 & 2604 & 373 & 14.3 \\
\hline Luxemburg & 1606 & 1128 & 70.2 & 1634 & 895 & 54.8 \\
\hline Netherlands & 2841 & 1879 & 66.1 & 2878 & 1450 & 50.4 \\
\hline Portugal & 2098 & 833 & 39.7 & 2134 & 213 & 10.0 \\
\hline Spain & 2627 & 1111 & 42.3 & 2654 & 562 & 21.2 \\
\hline Sweden & 2889 & 2021 & 70.0 & 2921 & 1755 & 60.1 \\
\hline Total & 41821 & 25056 & 59.9 & 42256 & 16774 & 39.7 \\
\hline
\end{tabular}


Table 6: Estimates for the International calls price equation

\begin{tabular}{|c|c|c|c|c|}
\hline \multirow[b]{2}{*}{ VARIABLES } & \multicolumn{4}{|c|}{ International calls price } \\
\hline & A & $\mathrm{B}$ & $\mathrm{C}$ & $\mathrm{D}$ \\
\hline $\log (A T R I)$ & $\begin{array}{c}0.404^{* * *} \\
(0.151)\end{array}$ & $\begin{array}{c}0.040 \\
(0.175)\end{array}$ & & \\
\hline Entry regulation & & & $\begin{array}{c}0.010 \\
(0.023)\end{array}$ & $\begin{array}{l}-0.024 \\
(0.023)\end{array}$ \\
\hline log(Public ownership) & & & $\begin{array}{c}0.002 \\
(0.023)\end{array}$ & $\begin{array}{c}0.008 \\
(0.021)\end{array}$ \\
\hline $\log$ (Market structure) & & & $\begin{array}{c}0.865 * * * \\
(0.315)\end{array}$ & $\begin{array}{c}0.287 \\
(0.322)\end{array}$ \\
\hline $\log ($ lines) & $\begin{array}{c}-2.727 * * \\
(1.232)\end{array}$ & $\begin{array}{l}-1.537 \\
(1.197)\end{array}$ & $\begin{array}{l}-2.138 * \\
(1.263)\end{array}$ & $\begin{array}{l}-0.917 \\
(1.194)\end{array}$ \\
\hline $\log$ (investments) & $\begin{array}{c}-1.014 * * * \\
(0.326)\end{array}$ & $\begin{array}{c}-0.733^{* *} \\
(0.314)\end{array}$ & $\begin{array}{l}-0.639 * \\
(0.326)\end{array}$ & $\begin{array}{l}-0.460 \\
(0.301)\end{array}$ \\
\hline log(isdn_channels) & $\begin{array}{l}-0.131 \\
(0.083)\end{array}$ & $\begin{array}{c}0.033 \\
(0.087)\end{array}$ & $\begin{array}{c}-0.191 * * \\
(0.079)\end{array}$ & $\begin{array}{c}0.039 \\
(0.090)\end{array}$ \\
\hline $\log ($ mob subscribers) & & $\begin{array}{c}-0.471 * * * \\
(0.132)\end{array}$ & & $\begin{array}{c}-0.534 * * * \\
(0.132)\end{array}$ \\
\hline $\log$ (density) & $\begin{array}{l}-0.686 \\
(3.299)\end{array}$ & $\begin{array}{l}-1.248 \\
(3.073)\end{array}$ & $\begin{array}{l}-4.997 \\
(3.255)\end{array}$ & $\begin{array}{l}-3.854 \\
(2.980)\end{array}$ \\
\hline Constant & $\begin{array}{c}-4.792 \\
(15.672)\end{array}$ & $\begin{array}{c}0.269 \\
(14.324)\end{array}$ & $\begin{array}{c}14.470 \\
(15.448)\end{array}$ & $\begin{array}{c}12.565 \\
(13.693)\end{array}$ \\
\hline Observations & 92 & 92 & 93 & 93 \\
\hline R-squared & 0.658 & 0.709 & 0.658 & 0.721 \\
\hline Number of country_id & 15 & 15 & 15 & 15 \\
\hline $\mathrm{J}$ test & 1.34 & 1.29 & 0.84 & 0.82 \\
\hline $\mathrm{p}$ value & 0.24 & 0.732 & 0.359 & 0.8435 \\
\hline Arellano-Bond test for AR(2) & -1.10 & -1.03 & -1.16 & -1.54 \\
\hline $\mathrm{p}$ value & 0.273 & 0.302 & 0.245 & 0.124 \\
\hline Hausman Test & 18.04 & 64.65 & 29.82 & 27.84 \\
\hline $\mathrm{P}$ value & $0.000^{* * *}$ & $0.000^{* * *}$ & $0.000^{* * *}$ & $0.000^{* * *}$ \\
\hline
\end{tabular}

Standard errors in parentheses

*** $\mathrm{p}<0.01, * * \mathrm{p}<0.05$, * $\mathrm{p}<0.1$ 
Table 7: Estimates for the National calls price equation

\begin{tabular}{|c|c|c|c|c|}
\hline \multirow[b]{2}{*}{ VARIABLES } & \multicolumn{4}{|c|}{ National calls price } \\
\hline & A & $\mathrm{B}$ & $\mathrm{C}$ & $\mathrm{D}$ \\
\hline $\log (\mathrm{ATRI})$ & $\begin{array}{c}0.343^{* * *} \\
(0.099)\end{array}$ & $\begin{array}{c}0.174 \\
(0.119)\end{array}$ & & \\
\hline Entry regulation & & & $\begin{array}{c}0.020 \\
(0.015)\end{array}$ & $\begin{array}{c}0.007 \\
(0.015)\end{array}$ \\
\hline log(Public ownership) & & & $\begin{array}{c}0.003 \\
(0.015)\end{array}$ & $\begin{array}{c}0.004 \\
(0.014)\end{array}$ \\
\hline $\log$ (Market structure) & & & $\begin{array}{c}0.579 * * * \\
(0.198)\end{array}$ & $\begin{array}{l}0.370 * \\
(0.221)\end{array}$ \\
\hline $\log ($ lines) & $\begin{array}{c}-1.511 * \\
(0.807)\end{array}$ & $\begin{array}{l}-0.865 \\
(0.817)\end{array}$ & $\begin{array}{l}-1.621 * \\
(0.813)\end{array}$ & $\begin{array}{l}-0.950 \\
(0.844)\end{array}$ \\
\hline $\log$ (investments) & $\begin{array}{c}-0.582 * * * \\
(0.214)\end{array}$ & $\begin{array}{c}-0.450 * * \\
(0.214)\end{array}$ & $\begin{array}{c}-0.551 * * \\
(0.216)\end{array}$ & $\begin{array}{c}-0.441 * * \\
(0.218)\end{array}$ \\
\hline log(isdn_channels) & $\begin{array}{c}-0.154^{* * *} \\
(0.054)\end{array}$ & $\begin{array}{c}-0.081 \\
(0.060)\end{array}$ & $\begin{array}{c}-0.180 * * * \\
(0.050)\end{array}$ & $\begin{array}{c}-0.102 * \\
(0.061)\end{array}$ \\
\hline $\log$ (mob subscribers) & & $\begin{array}{c}-0.216 * * \\
(0.090)\end{array}$ & & $\begin{array}{c}-0.193 * * \\
(0.094)\end{array}$ \\
\hline $\log$ (density) & $\begin{array}{l}-3.240 \\
(2.161)\end{array}$ & $\begin{array}{l}-3.437 \\
(2.099)\end{array}$ & $\begin{array}{l}-3.860 * \\
(2.161)\end{array}$ & $\begin{array}{l}-3.870 * \\
(2.117)\end{array}$ \\
\hline Constant & $\begin{array}{c}6.780 \\
(10.257)\end{array}$ & $\begin{array}{l}10.415 \\
(9.775)\end{array}$ & $\begin{array}{c}8.876 \\
(10.249)\end{array}$ & $\begin{array}{l}12.148 \\
(9.799)\end{array}$ \\
\hline Observations & 91 & 91 & 91 & 91 \\
\hline R-squared & 0.774 & 0.791 & 0.783 & 0.795 \\
\hline Number of country_id & 14 & 14 & 14 & 14 \\
\hline $\mathrm{J}$ test & 0.2 & 0.33 & 0.71 & 0.64 \\
\hline $\mathrm{p}$ value & 0.655 & 0.954 & 0.399 & 0.888 \\
\hline Arellano-Bond test for AR(2) & -0.81 & -1.17 & -1.46 & -1.48 \\
\hline $\mathrm{p}$ value & 0.419 & 0.241 & 0.145 & 0.140 \\
\hline Hausman Test & 58.67 & 19.58 & 23.52 & 18.34 \\
\hline$P$ value & $0.000^{* * *}$ & $0.003^{* * *}$ & $0.001^{* * *}$ & $0.011^{* *}$ \\
\hline
\end{tabular}

Standard errors in parentheses

*** $\mathrm{p}<0.01,{ }^{* *} \mathrm{p}<0.05,{ }^{*} \mathrm{p}<0.1$ 
Table 8: Estimates for the Local calls price equation

\begin{tabular}{|c|c|c|c|c|}
\hline \multirow[b]{2}{*}{ VARIABLES } & \multicolumn{4}{|c|}{ Local calls price } \\
\hline & A & $\mathrm{B}$ & $\mathrm{C}$ & $\mathrm{D}$ \\
\hline $\log (\mathrm{ATRI})$ & $\begin{array}{c}0.221^{* * *} \\
(0.047)\end{array}$ & $\begin{array}{c}0.209 * * * \\
(0.059)\end{array}$ & & \\
\hline Entry regulation & & & $\begin{array}{l}-0.009 \\
(0.007)\end{array}$ & $\begin{array}{l}-0.013^{*} \\
(0.007)\end{array}$ \\
\hline log(Public ownership) & & & $\begin{array}{c}0.019 * * * \\
(0.007)\end{array}$ & $\begin{array}{c}0.019 * * * \\
(0.007)\end{array}$ \\
\hline $\log$ (Market structure) & & & $\begin{array}{c}0.452 * * * \\
(0.095)\end{array}$ & $\begin{array}{c}0.361 * * * \\
(0.105)\end{array}$ \\
\hline $\log ($ lines) & $\begin{array}{l}-0.601 \\
(0.386)\end{array}$ & $\begin{array}{l}-0.722 * \\
(0.405)\end{array}$ & $\begin{array}{l}-0.455 \\
(0.380)\end{array}$ & $\begin{array}{l}-0.420 \\
(0.388)\end{array}$ \\
\hline $\log$ (investments) & $\begin{array}{l}-0.098 \\
(0.102)\end{array}$ & $\begin{array}{l}-0.087 \\
(0.106)\end{array}$ & $\begin{array}{c}0.028 \\
(0.098)\end{array}$ & $\begin{array}{c}0.055 \\
(0.098)\end{array}$ \\
\hline log(isdn_channels) & $\begin{array}{c}0.163 * * * \\
(0.026)\end{array}$ & $\begin{array}{c}0.167 * * * \\
(0.030)\end{array}$ & $\begin{array}{c}0.127 * * * \\
(0.024)\end{array}$ & $\begin{array}{c}0.158^{* * *} \\
(0.029)\end{array}$ \\
\hline $\log ($ mob subscribers) & & $\begin{array}{l}-0.015 \\
(0.044)\end{array}$ & & $\begin{array}{c}-0.078 * \\
(0.043)\end{array}$ \\
\hline $\log$ (density) & $\begin{array}{l}-1.568 \\
(1.034)\end{array}$ & $\begin{array}{l}-1.639 \\
(1.039)\end{array}$ & $\begin{array}{c}-3.567 * * * \\
(0.980)\end{array}$ & $\begin{array}{c}-3.386 * * * \\
(0.969)\end{array}$ \\
\hline Constant & $\begin{array}{l}-1.086 \\
(4.911)\end{array}$ & $\begin{array}{l}-3.430 \\
(4.844)\end{array}$ & $\begin{array}{l}7.788^{*} \\
(4.649)\end{array}$ & $\begin{array}{c}4.919 \\
(4.451)\end{array}$ \\
\hline Observations & 92 & 92 & 93 & 93 \\
\hline R-squared & 0.391 & 0.396 & 0.426 & 0.453 \\
\hline Number of country_id & 15 & 15 & 15 & 15 \\
\hline $\mathrm{J}$ test & 0.29 & 0.47 & 1.64 & 0.33 \\
\hline $\mathrm{p}$ value & 0.590 & 0.925 & 0.200 & 0.67 \\
\hline Arellano-Bond test for $\mathrm{AR}(2)$ & -1.27 & -1.26 & -1.45 & -1.59 \\
\hline $\mathrm{p}$ value & 0.204 & 0.206 & 0.147 & 0.111 \\
\hline Hausman Test & 72.97 & 18.51 & 25.41 & 15.35 \\
\hline$P$ value & $0.000^{* * *}$ & $0.000^{* * *}$ & $0.000^{* * *}$ & $0.000^{* * *}$ \\
\hline
\end{tabular}

Standard errors in parentheses

*** $\mathrm{p}<0.01, * * \mathrm{p}<0.05$, * $\mathrm{p}<0.1$ 
Table 9: Estimates for the Connection charge equation

\begin{tabular}{|c|c|c|c|c|}
\hline \multirow[b]{2}{*}{ VARIABLES } & \multicolumn{4}{|c|}{ Connection charge } \\
\hline & A & $\mathrm{B}$ & $\mathrm{C}$ & $\mathrm{D}$ \\
\hline $\log (\mathrm{ATRI})$ & $\begin{array}{c}0.211^{* *} \\
(0.105)\end{array}$ & $\begin{array}{l}-0.057 \\
(0.138)\end{array}$ & & \\
\hline Entry regulation & & & $\begin{array}{l}-0.019 \\
(0.018)\end{array}$ & $\begin{array}{c}-0.058^{* * *} \\
(0.017)\end{array}$ \\
\hline log(Public ownership) & & & $\begin{array}{l}-0.001 \\
(0.014)\end{array}$ & $\begin{array}{l}-0.001 \\
(0.013)\end{array}$ \\
\hline $\log$ (Market structure) & & & $\begin{array}{c}0.278 \\
(0.245)\end{array}$ & $\begin{array}{l}-0.232 \\
(0.241)\end{array}$ \\
\hline $\log ($ lines) & $\begin{array}{c}2.380^{* *} \\
(1.129)\end{array}$ & $\begin{array}{c}3.174 * * * \\
(1.115)\end{array}$ & $\begin{array}{l}2.417 * \\
(1.249)\end{array}$ & $\begin{array}{c}2.491^{* *} \\
(1.044)\end{array}$ \\
\hline $\log$ (investments) & $\begin{array}{l}-0.289 \\
(0.271)\end{array}$ & $\begin{array}{l}-0.154 \\
(0.263)\end{array}$ & $\begin{array}{l}-0.222 \\
(0.273)\end{array}$ & $\begin{array}{l}-0.062 \\
(0.247)\end{array}$ \\
\hline log(isdn_channels) & $\begin{array}{c}-0.043^{* * *} \\
(0.009)\end{array}$ & $\begin{array}{c}-0.037 * * * \\
(0.009)\end{array}$ & $\begin{array}{c}-0.124^{* * *} \\
(0.027)\end{array}$ & $\begin{array}{c}-0.033^{* * *} \\
(0.009)\end{array}$ \\
\hline $\log ($ mob subscribers) & & $\begin{array}{c}-0.215^{* * *} \\
(0.075)\end{array}$ & & $\begin{array}{c}-0.333^{* * *} \\
(0.069)\end{array}$ \\
\hline $\log$ (density) & $\begin{array}{l}-3.975 \\
(2.798)\end{array}$ & $\begin{array}{l}-3.519 \\
(2.687)\end{array}$ & $\begin{array}{c}-6.255^{* *} \\
(2.513)\end{array}$ & $\begin{array}{l}-3.692 \\
(2.283)\end{array}$ \\
\hline Constant & $\begin{array}{c}20.150 \\
(13.319)\end{array}$ & $\begin{array}{c}19.990 \\
(12.734)\end{array}$ & $\begin{array}{c}30.531^{* *} \\
(11.924)\end{array}$ & $\begin{array}{l}21.091 * \\
(10.716)\end{array}$ \\
\hline Observations & 100 & 100 & 101 & 101 \\
\hline R-squared & 0.445 & 0.497 & 0.434 & 0.564 \\
\hline Number of country_id & 15 & 15 & 15 & 15 \\
\hline $\mathrm{J}$ test & 1.89 & 0.63 & 1.2 & 1.01 \\
\hline $\mathrm{p}$ value & 0.169 & 0.889 & 0.273 & 0.603 \\
\hline Arellano-Bond test for $\mathrm{AR}(2)$ & -0.06 & 0.33 & -0.05 & -0.10 \\
\hline $\mathrm{p}$ value & 0.954 & 0.745 & 0.962 & 0.922 \\
\hline Hausman Test & 8.73 & 15.77 & 120.90 & 16.83 \\
\hline$P$ value & $0.071^{*}$ & $0.007^{* * * *}$ & $0.000^{* * *}$ & $0.009^{* * *}$ \\
\hline
\end{tabular}

Standard errors in parentheses

*** $\mathrm{p}<0.01,{ }^{* *} \mathrm{p}<0.05,{ }^{*} \mathrm{p}<0.1$ 
Table 10: Consumers' satisfaction: main estimation results from the probit model.

\begin{tabular}{|c|c|c|c|c|}
\hline \multirow{3}{*}{ Price local calls } & \multicolumn{4}{|c|}{ Marginal Effects } \\
\hline & \multicolumn{2}{|l|}{ Price } & \multicolumn{2}{|c|}{ Quality } \\
\hline & $0.137^{* *}$ & $0.367 * * *$ & $0.206^{* * *}$ & $0.485^{* * *}$ \\
\hline Price national calls & $-0.063^{* *}$ & $-0.099 * * *$ & $0.058 *$ & 0.024 \\
\hline Price international calls & $-0.220 * * *$ & $-0.260 * * *$ & $-0.061^{*}$ & $-0.121 * * *$ \\
\hline Entry regulation & & $0.028 * * *$ & & $0.037 * * *$ \\
\hline Public ownership & & $-0.028 * *$ & & -0.017 \\
\hline Market structure & & $-0.062^{* * *}$ & & $-0.105^{* * *}$ \\
\hline Female & $-0.016^{* *}$ & $-0.016 * *$ & -0.005 & -0.005 \\
\hline Age & $-0.009 * * *$ & $-0.009^{* * *}$ & -0.002 & -0.002 \\
\hline $\operatorname{Age}^{\wedge} 2$ & $0.000^{* * *}$ & $0.000^{* * *}$ & 0.000 & 0.000 \\
\hline single & 0.004 & 0.005 & -0.012 & -0.011 \\
\hline separated/divorced/widowed & $-0.053^{* * *}$ & $-0.052 * * *$ & $-0.017 *$ & -0.015 \\
\hline Age when finished education & $0.010^{* * *}$ & $0.010^{* * *}$ & -0.002 & -0.002 \\
\hline Age when finished education $\wedge 2$ & $-0.000 * * *$ & $0.000 * * *$ & 0.000 & 0.000 \\
\hline manager & -0.022 & -0.021 & 0.011 & 0.013 \\
\hline other white collar & -0.017 & -0.017 & 0.001 & 0.001 \\
\hline manual worker & -0.023 & -0.023 & $-0.025^{*}$ & $-0.025 *$ \\
\hline house person & -0.009 & -0.009 & 0.008 & 0.007 \\
\hline unemployed & $-0.080 * * *$ & $-0.081 * * *$ & -0.030 & -0.030 \\
\hline retired & $-0.035 *$ & $-0.035 * *$ & -0.011 & -0.012 \\
\hline student & $0.149 * * *$ & $0.147 * * *$ & -0.030 & -0.033 \\
\hline political views: centre & $0.024^{* *}$ & $0.024^{* *}$ & 0.010 & 0.009 \\
\hline political views: right & -0.003 & -0.003 & $0.027 * *$ & $0.028 * * *$ \\
\hline political views: d.k./n.a. & -0.016 & -0.015 & 0.002 & 0.002 \\
\hline respondent's cooperation: average/bad & $-0.029 * *$ & $-0.030 * *$ & $-0.034 * * *$ & $-0.035^{* * *}$ \\
\hline Population Density & $0.013^{* * *}$ & $0.012 * * *$ & 0.001 & -0.002 \\
\hline Real GDP growth Rate & $0.014^{*}$ & 0.01 & $0.034^{* * *}$ & $0.031^{* * *}$ \\
\hline Inflation Rate & $0.029 * * *$ & $0.047 * * *$ & -0.010 & 0.006 \\
\hline CPI & 0.008 & 0.007 & 0.007 & 0.005 \\
\hline GDP per capita & -0.002 & 0.003 & -0.003 & $0.004^{*}$ \\
\hline Yearly employment growth & -0.006 & -0.004 & $0.014^{* *}$ & $0.019 * * *$ \\
\hline GINI & $-0.017^{* * *}$ & $-0.015^{* * *}$ & $-0.008^{*}$ & -0.002 \\
\hline year=2002 & -0.038 & $-0.111^{* * *}$ & $0.041 *$ & $-0.055^{* *}$ \\
\hline year=2004 & $0.093 * * *$ & 0.024 & $0.057 * * *$ & -0.039 \\
\hline Austria & $0.437 * * *$ & $0.435 * * *$ & 0.103 & -0.175 \\
\hline Belgium & $-0.626^{* * *}$ & $-0.620 * * *$ & -0.181 & 0.374 \\
\hline Denmark & $0.425^{* * *}$ & $0.423^{* * *}$ & 0.302 & 0.076 \\
\hline Finland & $0.443^{* * *}$ & $0.442 * * *$ & 0.277 & -0.114 \\
\hline France & $0.643^{* * *}$ & $0.647 * * *$ & -0.025 & -0.154 \\
\hline Germany & $-0.204^{* *}$ & -0.022 & $-0.163^{* *}$ & 0.031 \\
\hline Greece & $0.455^{* * *}$ & 0.46 & -0.122 & -0.047 \\
\hline Ireland & $0.426^{* * *}$ & $0.424 * * *$ & 0.176 & -0.162 \\
\hline Italy & 0.006 & $0.201 * * *$ & $-0.216^{*}$ & 0.019 \\
\hline \multicolumn{5}{|l|}{ Luxemburg } \\
\hline Netherlands & $-0.746^{* * *}$ & -0.728 & -0.175 & $0.626^{*}$ \\
\hline Portugal & $0.433 * * *$ & $0.436 * * *$ & -0.207 & -0.083 \\
\hline Spain & $0.584 * * *$ & $0.595 * * *$ & -0.148 & -0.129 \\
\hline Sweden & $0.466^{* * *}$ & $0.465^{* * *}$ & 0.342 & 0.005 \\
\hline Constant & $-6.104 * *$ & $-4.633^{* *}$ & 2.724 & $4.953^{* *}$ \\
\hline Observations & 38479 & 38479 & 38847 & 38847 \\
\hline Pseudo-R2 & 0.121 & 0.119 & 0.067 & 0.068 \\
\hline Frequency of correct predictions (\%) & 66.1 & 66.3 & 63.9 & 64.1 \\
\hline Log-Likelihood & -22987.6 & -23027 & -22959.265 & -22929.967 \\
\hline
\end{tabular}

Robust p values in brackets - * significant at $10 \%$; ** significant at 5\%; *** significant at $1 \%$ 